\title{
Drivers of Clan Conflicts: A Perspective of the Role of Al- Shabaab in Garissa County, Kenya
}

\author{
Stephen, K. Rotich ${ }^{1}$, Warfa, O. Ahmed ${ }^{2}$ \\ ${ }^{1}$ School of Education, Garissa University, Kenya \\ ${ }^{2}$ School of Education, Garissa University, Kenya \\ rotichkipkorir94@gmail.com
}

\section{Abstract}

The purpose of the study was to investigate the relationship between the drivers of intra-clan-based conflicts and the involvement of external actors that has remained indefinable in Garissa County. The three sub-counties: Garissa Township, Ijara and Fafi were purposively selected for the study because of prolonged and unresolved intra-clan conflicts coupled with militia group of Al-Shabaab attacks over the past years. Qualitative approach was used to seek understanding of drivers of intra-clan conflicts and involvement of violent extremism. The study involves primarily 35 Key Informants drawn from security agencies, Clan elders, Religious leaders and Civil societies across the three sub-counties. The study established that competition over natural resources: water; pasture and land are the main causes of intra-clan conflicts. The respondents attest that intra-clan conflicts have been accelerated by clan identity politics, poverty, illiteracy, unemployment and Al-Shabaab infiltration. The devolution has elevated competition for political leadership due to sharing of county resources and employment along the sub-clans. The study found some respondents attributing Kenya's military operation in Somalia to reciprocal attacks by Al-Shabaab in the county. The research established that over the years, Somali clan conflicts and hostility have spilled over into North Eastern Kenya, creating security threat and undermining community peace and cohesion. The porous border of Kenya-Somali has made it easy for some sub-clans to communicate with their kinsmen's counterparts and obtain guns that are readily available in Somalia. The perception of injustices and sense of marginalization amongst the Muslims have provided fertile ground for Al-Shabaab which has diverted attention of security agencies to violent extremism rather than clan conflicts. The study recommends enhancement of inclusive peace committee and collaboration of community with administration and security agencies to tie together peace. There is also a need for openness of politicians to advocate for impartiality, clan conflicts resolution and countering violent extremism through policy framework in the county assembly. 


\section{Introduction}

The emergent of Al-Shabaab in Southern and Central Somalia in 2006, that describe itself as waging jihad against 'enemies of Islam' has continued to raise security concern globally. Kenya has experienced frequent attacks by the militia group, especially Northern Kenya, Nairobi, and Coast. Al-Shabaab has caused a number of attacks in Garissa county with more frequent attacks in Ijara sub-county. The role of the militia group in clan conflicts and reasons for terrorism has been hard to define, in spite of impairment to peace in the county. This has caused fear among the residents of Garissa, and has necessitated the need for this study to dig up more on how they permeate into the clan dynamic forces.

Majority of the residents in Garissa County are pastoralists and keep cattle, goats and camels (Anderson,2015). Some of the residents carry out small businesses and farming along Tana River. The types of communities living in the area are Somali, Borana and Pokomo. The main clan in the area is Ogaden who migrated from Southern Somalia and is made up of sub-clans of Aulihan (Lagdera, Dadaab); Audwak (Fafi and Balambala) and Abdalla (Ijara). All the clan groups subscribe to the Islamic religion.

The specific locations of Garissa Township, Ijara and Fafi were selected for the study because of prolonged and unresolved intra-clan conflicts coupled with militia group of AlShabaab attack over the past years. Garissa Township has Audwak dominating political leadership in comparison to the other clans of Aulihan and Abdalla. Fafi is dominated by Audwak, however, Aulihan who are attracted by business and pastures are significant in the area. Ijara has the main sub-clan of Abdalla fighting for resources with Pokomo of Tana River county escalating cross county border conflicts.

The study areas have suffered Al-Shabaab attacks and its relationship with clan conflicts is complex. Security incident analysis conducted by RUSI (2017) reveals that out of the 55 major incidents reported, 16\% were reported in Garissa, 22\% in Mandera and 5\% in Wajir County. On 30th December, 2017, Somali based militia group of Al-Shabaab set fire on two police stations and destroyed Safaricom mast in Ijara town before escaping with a police land cruiser (Orinde,2017). The attackers also looted a shop in Ijara town. The cases of Al-Shabaab insecurity have been reported in Hulugho and along the bordering Boni forest in Fafi sub-county. The insecurity situation has caused fear among residents. Garissa Township suffered a major militia group of Al-Shabaab attack with 147 deaths of students at Garissa University College on 2nd April, 2015.It has not become clear if AlShabaab militia contributes to clan conflicts in the region.

\section{Objectives of the Study}

1. To establish the drivers of intra-clan conflicts in Garissa county, Kenya

2. To assess the relationship between intra-clan conflicts and Al-Shabaab involvement in the conflicts in Garissa county, Kenya

3. To identify mitigation strategy of clan conflicts and external actors' engagement

\section{Methodology}

The study adopted qualitative approach that was considered appropriate for expounding and interpreting the occurrence in the area. The approach was used to seek understanding of drivers of clan conflicts and involvement of Al-Shabaab. Badurdeen (2018) says narratives are used to comprehend individual experiences. The study involves primarily Key Informants to obtain in-depth information that depicts the status of the variables in the study. The primary data was collected by two Research Assistants (RAs) 
using Key Informant Interview Guide. The Guide had structured questions to guide RAs in generating story lines for each category of respondents. The RAs were trained by the researcher on how to conduct dialogues, generate narratives on the research questions. The implementation was overseen by the researcher to ensure that the notes written down during interviews are relayed immediately to the Researcher to collate and analyze.

Data for this study was collected in Garissa based on the sampling frame that was stratified into four categories as; clan elders, security officers, religious leaders and Civil society organizations. Purposive sampling was used to obtain the required number of respondents in each category of the target population. There was a total of 35 respondents interviewed from the three sub-counties of Garissa Township, Fafi and Ijara.

Table 1. Distribution of respondents in the three sub-counties

\begin{tabular}{|lllll|}
\hline Sampling Frame & \multicolumn{3}{l}{ Sample Size } \\
& Garissa & Ijara & Fafi & Total \\
Clan elders & 4 & 4 & 3 & 11 \\
Religious leaders & 4 & 3 & 3 & 10 \\
Civil societies & 1 & 1 & 1 & 3 \\
Security agents & 4 & 4 & 3 & 11 \\
Total & & & & 35 \\
\hline
\end{tabular}

The respondents were subjected to interview to generate information for understanding drivers of clan conflicts and mitigation strategies in study areas. The risks and limitations of the findings were underscored as the information presented was carefully chosen not to cause any harm to participants and researchers. Some participants feared to provide information especially those related to violent extremism. However, they were assured of confidentiality and freedom to participate or withdraw at any stage of the interview.

\section{Discussion}

\subsection{Causes and Contributing Factors of Intra-clan Conflicts}

The outcomes of this research are grounded on the analysis of the interviews with selected respondents in Garissa Township, Ijara and Fafi. The respondents demonstrated that there have been incidents of intra-clan conflicts couple with the Al-Shabaab threat in the area for the past two years.

\section{a. Competition over Scarce Natural Resources}

The main causes of the intra-clan conflicts were found to be competition over natural resources such as water, pastures and land. The study established that clan conflicts are mainly contributed by Al-Shabaab militia and political control in the county leadership. Pokomo cross the Tana River to do farming in Ijara while Abdalla are pastoralists. The conflicts occur where Abdalla of Ijara in Garissa county crosses to county of Tana River to graze their livestock during drought. The chief and clan elders of the area have been resolving the conflicts despite its re-occurrence. The other conflicts were found to occur between Abdalla and Aulihan of Garissa Township over boundary disputes and political supremacy. In Fafi, the Audwak considers others as immigrants and compete for businesses.

A participant expresses his concern when asked why they fight each other; 
"We cannot sit and watch our livestock dying. We have to look for pastures for them. When they fight us, we defend our livestock and ourselves"

Reduced access to pastures and water due to prolonged drought in Garissa County has escalated intense pressure for the scarce resources. As a result, they fight for their survival culminating to retaliation of clan deaths due to revenge killings. The three subclans of Audwak, Aulihan and Abdallah in Garissa Township fight for resources such as land (plots) especially in Waberi east location. Aulihan and Audwak fight for resources in Dujus village of Fafi.

\section{b. Clan Identity Politics}

There is scramble for clan political leadership in Garissa County. All the clans fight for political supremacy.

Table 2. Distribution of political seats in Garissa County

$\begin{array}{ll}\text { Political seat } & \text { Clan } \\ \text { Governor } & \text { Audwak } \\ \text { Women Representative } & \text { Audwak } \\ \text { Senator } & \text { Abdallah } \\ \text { MP (Ijara) } & \text { Abdallah } \\ \text { MP (Garissa Township) } & \text { Audwak } \\ \text { MP (Balambala) } & \text { Audwak } \\ \text { MP (Fafi) } & \text { Audwak } \\ \text { MP (Dadaab) } & \text { Aulihan } \\ \text { MP (Lagdera) } & \text { Aulihan }\end{array}$

The Audwak dominates the political seats. The Abdallah and Aulihan are marginalized in the politics of Garissa County. The study established that there are some clan elders and youths who are engaged by politicians to defend their clans and fight for the seats. The clan conflicts were attributed to politicians who indulge their clans during the clashes. The roles and interests of the politicians are to provide financial support to their clan members and gain political supremacy and dominance in the area. Some politicians favour their clan of origin and ignore opposing clans. The respondents mentioned leaders of the Audwak clan dominating sharing of county positions and resources. The other clans feel politically excluded. One respondent said;

"Our youths have gone to seek employment in Wajir because our county is biased.

Some have run away to Somalia".

The county government resources and the political representation have aggravated the existing inter clan conflicts. The control of elective seats seems be assurance for access to economic resources. When a member of a clan wins the elections, he or she allocates government projects and job vacancies to their kinsmen. One respondent narrates:

"Politics in this area is based on clannism. When the election is over, the winning clan controls resources. Audwak has dominated the major county positions. The other clans fight for their survival for resources and job opportunities. This fight has given chance the infiltration of Al-Shabaab" 
Some of the participants reported that some clans have acquired guns from Somalia. When asked about the presence of guns, one participant said:

"There are guns everywhere; they are avail when there are clashes. When there is no fight, you cannot see them. There are immigrants of Somalia in the area. Guns are readily accessible in Somalia. They are sold in the market."

The respondents attributed clan conflicts to politicians' self- interest who disregard some clans and favour their clans of origin by providing financial support to their clan members so as to gain political supremacy and dominance in the area. There is scramble for county government resources, employment and tender awards. The participants attest that politics contribute to clan conflicts especially during political campaigns which are characterized by incitements and tensions among the clans.

\section{c. Business Competition}

There are cross-border county conflicts between Abdalla and Pokomo in Ijara and Tana River over grazing and farming along the Tana river. The Aulihan and Audwak in Fafi and Hulugho hub scramble for trade in the area. The Audwak, Aulihan and Abdallah in Garissa Township compete for plots, tenders and employment opportunities in the county.

\subsection{The Role of Al-Shabaab in Intra-clan Conflicts}

The respondents narrated that clan militia are targets for radicalization by AlShabaab. Some youths normally disappeared from the community. Those who come back (Al-Shabaab Returnees)

The study found that the residents do not help in exposing the militia due to fear of being exposed to militia as traitors or being used by security to help in searching for the militia. There are extra judicial killings to Muslim youths both in Somalia and Kenya by Kenya Defense Force (KDF). One participant said:

"It is not easy now to tell who Al Shabaab is and they are with us. We fear talking about them. The Al-Shabaab are in different forms. There are sympathizers, informers and violent extremists who lodge attacks when required by their leaders. Al- Shabaab are not happy about the present of Kenya security in Somalia and they use any means to frustrate the Kenya government".

The contributing factors that have compounded to Intra-clan conflicts and infiltration of Al-Shabaab in the county are: the porous border of neighboring countries, political differences among the clans, poverty, illiteracy, poor communication network, and lack of political goodwill to resolve the clan conflicts. The youths have impunity to raid other clans so as to amass wealth and gain access to scarce pastures and water.

The study found the long history of regional conflicts and the participation of Kenyan security in Somalia as a contributing factor. There are cross border clan alliances, where clans from Somalia coming to support their kinsmen in Kenya due to permeable borders. It was reported that the youths who leave for Somalia also come back to support their community. The study was informed that there is smuggling of fire arms contributing to easy access to guns by residents which escalate the clan conflicts.

Fafi is much nearer to the border of Somalia, accessing weapons is much easier. The Boni forest which is characterized by bush and shrubs has been a major hide out for the Al-Shabaab militia in Lamu County which boarders Ijara and Fafi. One participant said:

"Al-Shabaab is no longer affairs of Somalis alone. Different tribes who are nonSomalis have joined the extremist group. It is not easy now to tell who Al-Shabaab is 
and they are with us. We fear talking about them. The Al-Shabaab is in different forms and has infiltrated most parts of the county. There are sympathizers, informers and violent extremists who lodge attacks when required by their leaders. Al-Shabaab are not happy about the present of Kenya security in Somalia".

One respondent replied when asked if there has been any involvement of actors from neighbouring countries in clan conflicts:

"There are Somali citizens who migrated into Kenya illegally and some provide firearms, to clan members, which are later used during conflicts"

When Security agents invaded Boni forest, some Al-Shabaab moved to Ijara where they cause attacks to government officers, business people and forcing youths grazing livestock to follow them or be killed. Some respondents said that they kidnap the youths to radicalize and use them to further their interest.

\subsection{Existing Mitigation Strategy}

The study affirms that security measures have been put in place to resolve clan conflicts although the security agencies concentrate on fighting Al-Shabaab. The measures include sharing of intelligence information between different security organs and elders, recruiting and training of police reservist drawn from the local community, training the community on policy and Nyumba Kumi Programmes, deploying more security officers and opening of new police posts or camps. The participants reported that the measures have reduced clan conflicts. However, they argued that there are still persisting challenges of Al-Shabaab taking advantage of clan conflicts and perceived marginalization of the area by the Government to infiltrate the community and carry out attacks against the non-locals and the government agencies.

\subsection{Recommendations}

The mitigation strategies should target fostering inclusive collaboration of community members with security agencies.

The County assembly should enact and enforce Policy framework on clan impartiality when sharing resources among the clans.

The security agencies should engage stakeholders on mechanisms of countering radicalization and violent extremism.

The areas of research that need to be explored in greater detail are effectiveness of Home Guards/Security Reservists in reinforcement of security and assessment of security effectiveness along Kenya -Somalia Border.

The existing Peace Committee should organize inter-clan meetings together with politicians to resolve the conflicts and violent extremism.

On the other hand, the assistant chief, elders and religious leaders should meet regularly to resolve land, boundary disputes and liaise with security agencies.

The police should arrest the culprits and take them to court of justice to avoid judicial killings that aggregate sympathy from the community.

The Youth Groups should be financially supported to spearhead entrepreneurship such as Boda-Boda, Tuk-Tuk, and cyber business, among others. The county government should consider equity among the sub-clans for employment opportunities.

The grazing boundaries need to be marked and enforced.

There is need to encourage intermarriage among the clans as peace mitigation strategy among the youths. 


\section{Conclusion}

The research found that over the years, clan conflicts in Somalia have spilled over into North eastern Kenya with cross-border clans associations. This has given the AlShabaab an advantage to gain access to the Kenya. Al-Shabaab is a Somalia- based Islamist group and is part and parcel of the Somali clans. Despite being militia and feared, they are not rejected by their kinsmen and further their interests through radicalization. The militia group take advantage of vulnerable residents where majority are not in formal employment nor business and where dominant clans undermine others in political leadership.

The perception of historical injustices done to Muslims by security agents using hard approach; extra judicial killing, harassment and tagging Muslims as terrorists, scramble for natural resources for the livestock and human livelihood, political leadership positions, tenders, plots and employment opportunities in Garissa county have contributed to clan conflicts and rich ground for Al-Shabaab to penetrate the discontented residents.

The relationship between Al Shabaab and clan conflicts lean on support and recruitment of clan youths to Al-Shabaab to further the radicalization, spying and violent extremism.

\section{References}

Anderson,M.D. (2015). Understanding Al-Shabaab: Clan, Islam, and Insurgency in Kenya. Journal of Eastern African Studies,Vol. 9, 2015-issue 3.Published online; 23 Sept.2015.

Borum,R. (2011). "Radicalization into Violent Extremism 1: A Review of Social Science Theories", Journal of Strategic Security 4, (4):7-36'.

Botha, A. (2014). "Radicalization in Kenya. Recruitment to Al-Shabaab and the Mombasa Republic Council", Institute for Security Studies Papers, 265.

Budurdeen, F. (2018). Violent Extremism and Gender in Kenya. A Journal of African Politics, Development and International Affairs, Vol. 45, No. 1: Dar es Salaam.

Garissa County Steering Group and Kenya Food Security Steering Group (February,2016). Garissa County Annual Development Plan Report 2015.

Hassan, M. (2012). "Understanding drivers of violent extremism: The case of Al-Shabaab and Somali Youth"; https//ctc.usma.edu/understanding-drivers-of-violent-extremismthe-case-of-alshabaab and -somali-youth, access 10.6.2018

Jeremy, Lind; Mutahi, P; Oosterom, M.(2015). Tangled Ties: Al-Shabaab and Political Volatility in Policy Briefing Africa International Crisis Group (2012). Kenyan Somali Islamist Radicalization. Nairobi/Brussels.

Mwangi, G.0. (2012). Politics, Religion and Ideology. Journal of Eastern African Studies, Vol. 13 Issue 4.

Mueller, J.C. (2018). The Evolution of Political Violence: The Case of Somalia's AlShabaab. A journal of Terrorism and Political Violence,Vol. 30,2018-issue 1.Published online, 9 May 2016.

Ngala, C. (2016). Violent Extremism and Clan Dynamics in Kenya. Peace work number 123, United states of peace, Washington DC, Web: www.usip.org

Orinde, H. (2017, December 30). Al-Shabaab militia attack police camps in Ijara, Garissa county: Nairobi, Nation media.

Ruto, P., Mohamud, A. \& Isabella, M. (2003). Conflict in Northern Kenya. A Focus on the Internally Displaced Conflict Victims in Northern Kenya, DTP Karimi Publisher. 